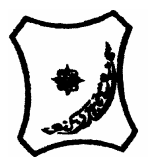

Bayero Journal of Pure and Applied Sciences, 9(2): 114 - 120

Received: April, 2016

Accepted: October, 2016

ISSN $2006-6996$

\title{
PLASMID MEDIATED RESISTANCE IN MULTIDRUG RESISTANT BACTERIA ISOLATED FROM CHILDREN WITH SUSPECTED SEPTICAEMIA IN ZARIA, NIGERIA
}

\author{
AbdulAziz, Z. A., ${ }^{1 *}$ Ehinmidu, J. O., ${ }^{1}$ Adeshina, G. O., ${ }^{1}$ Pala, Y. Y ${ }^{2}$, Yusuf, S. S $^{2}$ and \\ Bugaje, M. A. ${ }^{3}$ \\ ${ }^{1}$ Department of Pharmaceutics and Pharmaceutical Microbiology, Faculty of Pharmaceutical Sciences Ahmadu \\ Bello University, Zaria \\ ${ }^{2}$ Centre for Biotechnology Research, Ahmadu Bello University, Zaria \\ ${ }^{3}$ Department of Paediatrics, Ahmadu Bello University Teaching Hospital, Zaria \\ *Corresponding author: zubaydaabdul@gmail.com
}

\section{ABSTRACT}

Septicaemia is a common cause of morbidity and mortality among children in the developing world. The knowledge of the epidemiological and antimicrobial pattern of common pathogens that cause septicaemia is useful for prompt treatment of patients. Fifty-five (55) clinical isolates from children with suspected septicaemia were used for the study. The isolates include Coagulase negative Staphylococcus, Staphylococcus aureus, Salmonella spp., Klebsiella spp., Citrobacter spp., Proteus spp and Pseudomonas spp. The antibiotic susceptibility testing of isolated bacteria associated with septicaemia in children were carried out using standard microbiological protocol. The MAR index for the test bacterial isolates was determined and the bacterial isolates that displayed multiple antibiotic resistance were investigated for the presence of resistant factor such as plasmids. The sizes of the plasmid observed in the bacterial isolates were determined using agarose gel electrophoresis. Observations made from the agarose gel electrophoresis showed that majority of the multiple antibiotic resistant isolates haboured plasmids DNA of different sizes viz; $10.00 \mathrm{~Kb}$, $8.71 \mathrm{~Kb}, 7.08 \mathrm{~Kb}, 1.02 \mathrm{~Kb}, 1.00 \mathrm{~Kb}, 0.98 \mathrm{~Kb}$ and $0.87 \mathrm{~Kb}$. The plasmid analysis of the results obtained in this study showed that the predominant plasmid molecular size was $977 b p$ which occurred frequently among the Citrobacter spp and Staph aureus. These findings suggest an increased resistance to the antibiotics commonly used for the treatment of septicaemia, and the observed presence of plasmids in some of the test bacteria isolated shows that they could have been acquired from multiple antibiotic resistant bacteria in the community under investigation. Key words: Children, Multiple antibiotic resistance, Plasmids, Septicaemia

\section{INTRODUCTION}

Septicaemia remains a major cause of morbidity and mortality in children. In the developing countries they occur more often among neonates and young infants and are mainly community acquired (Alausa et al., 1977). While in the advanced countries they occur more often among elderly patients of which majority are hospital acquired following instrumentation and therapeutic procedures (Brunfitt and Leigh, 1969). The widespread use of antimicrobial agents against the high level of microbial infection in children is becoming a cause for increased concern. Resistant bacteria population flourishes in areas of high antimicrobial use, where they enjoy a selective advantage over susceptible population (Gordon and Ronald, 2005).

Frequently, a bacterial pathogen is drug resistant because it possesses plasmid that has one or more resistant genes. Plasmids have the ability to be transferred within and between species and can therefore be acquired from other bacteria. This property makes resistance due to plasmid much more threatening than resistance due to chromosomal mutation in terms of spread of antibiotics resistance (Hugo and Russell, 2004).
This study was carried out to investigate the antibiotic susceptibility pattern of bacteria isolates from children with suspected septicaemia in Institute of Child Health, Banzazzau, Ahmadu Bello University Teaching Hospital (ABUTH) Zaria and to assess whether antibiotic resistance in the isolated bacteria is plasmid or chromosomally mediated. It is hoped that with the findings from this study will give a guide to proper management septicaemia especially in upholding the existing empirical treatment of septicaemia, prior to obtaining culture results in a setting where there is limited resources and laboratory facilities for diagnosis and controlled use of antibiotics to prevent or minimize spread of antibiotic resistance to the locality. MATERIALS AND METHODS

Fifty-five (55) clinical isolates specifically bacteria from children with suspected septicaemia were used for the study. The isolates include Coagulase negative staphylococcus, Staphylococcus aureus, Salmonella spp, Klebsiella spp, Citrobacter spp, Proteus spp and Pseudomonas spp. Antibiotic susceptibility pattern was determined using Kirby Bauer disc diffusion method. Overnight nutrient broth cultures which had been standardized with $0.9 \% \mathrm{Nacl}$ solution to contain $10^{5} \mathrm{CFU} / \mathrm{ml}$ were inoculated on the surface of 
BAJOPAS Volume 9 Number 2 December, 2016

the agar and allowed to dry, after which the antibiotics were placed aseptically. This was allowed to stay for 30 minutes to allow diffusion of antibiotics into medium, and then incubated at $37^{\circ} \mathrm{C}$ for $24 \mathrm{hrs}$.

Determination of Minimum Inhibitory Concentration

The MIC was determined using eight antibiotics: cefuroxime, ceftriaxone, ciprofloxacin, ofloxacin, gentamicin, erythromycin, streptomycin and chloramphenicol, employing the agar plate dilution method (Lennette et al., 1990) with modifications. Freshly prepared stock solution of the various antibiotics were prepared in graded concentration $(0.7812-500 \mu \mathrm{g} / \mathrm{ml})$ of $5 \mathrm{ml}$ volume in triplcates and mixed aseptically with $5 \mathrm{ml}$ volume of double strength sterile Mueller Hinton's agar and allowed to set. Five (5) $\mathrm{ml}$ of sterile de-ionised distilled water mixed with $5 \mathrm{ml}$ double strength Mueller Hinton agar were set up as control. An 18 hours culture of the test isolates were standardized to an inoculum density of $10^{5} \mathrm{cfu} / \mathrm{ml}$ (Woods and Washington, 1995). The dried agar surface was aseptically inoculated with test organism in triplicates at equidistance. A positive control Mueller Hinton agar was inoculated with $20 \mu \mathrm{l}$ of the standardized over night-culture of test isolates $\left(10^{5} \mathrm{cfu} / \mathrm{ml}\right)$. The plates were allowed to stay for 30 minutes after which they were incubated at $37^{\circ} \mathrm{C}$ for 18 hours (Odama, 1990). They were thereafter examined for the presence or absence of growth. The lowest antibiotic concentration at which they were no visible growth was taken as the minimum inhibitory concentration (MIC). Peak blood plasma level as stated by Martindale (1996) was used as the break point.

MULTIPLE ANTIBIOTIC RESISTANCE INDEX The MAR index for the test bacterial isolates was determined according to the procedure described by Krumperman (1983). The indices were determined by dividing the number of antibiotics to which organisms were resistant (a) by the number of antibiotics tested (b). Resistant to three (3) or more antibiotics is taken as MAR.

Beta-Lactamase Production Test Suspension of the isolates was prepared by emulsifying bacterial colonies (from overnight cultures) in $0.5 \mathrm{ml}$ phosphate buffer solution containing $0.06 \mathrm{mg} / \mathrm{ml}$ penicillin $\mathrm{G}$. They were incubated at room temperature for at least an hour. Thereafter, 2 drops of freshly prepared $1 \%$ aqueous starch solution were added to each bacterial suspension and shaken. Then, one drop of iodine solution was added and allowed to stand for ten minutes. (Olayinka et al., 2005).

Isolation Of Plasmid DNA Sterile Luria-Bertani (LB) medium was inoculated with a single bacterial colony and incubated at $37^{\circ} \mathrm{C}$ for 24 hours to form a good growth to saturation. Exactly $1.5 \mathrm{ml}$ of cells was centrifuged for 1 minute at 8000rpm. Pellets were resuspended in $400 \mu$ l Glucose/Tris/EDTA (GTE) solution and allowed to stand for 5 minutes at room temperature. Two hundred (200) $\mu \mathrm{l}$ of $\mathrm{NaOH} / \mathrm{SDS}$ (Sodium hydroxide/Sodium dodecyl solution), was added and mixed well then placed on ice for five minutes. One hundred and fifty (150) $\mu$ l of potassium acetate solution, was added and vortexed briefly and placed on ice for 5 minutes. This was centrifuged at $10,000 \mathrm{rpm}$ for 5 minutes and supernatant transferred to a new tube. Eight hundred (800) $\mu$ l of $95 \%$ ethanol was added and minutes and supernatant decanted. Pellets were washed with $1 \mathrm{ml} 70 \%$ ethanol, centrifuged at $8000 \mathrm{rpm}$ for 5 minutes and supernatant decanted. The ethanol was air-dried and pellet re-suspended in 50 $\mathrm{ll}$ of Tris/EDTA (TE) buffer (Rederick et al.,1992).

Agarose Gel Electrophoresis of Plasmid DNA Agarose gel $(0.8 \%)$ was made by weighing $0.8 \mathrm{~g}$ of agarose in a conical flask and $100 \mathrm{ml}$ of 1 x TAE (Trisacetate $0.002 \mathrm{M}$ Ethylene diamine tetra acetic acid) buffer was added. This was solubilized by heating in a microwave oven and allowed to cool to $60{ }^{\circ} \mathrm{C}$ thereafter $5 \mu$ of ethidium bromide was added. It was then sealed by tape on edges with thumb nail in gel tray and comb was placed in position. The combs were placed near edge of gel and made sure that fingers of comb are slightly above the plate but not touching it. The agarose solution was placed into taped gel tray to make gel. Three hundred (300) $\mathrm{ml}$ of $1 \times$ TAE buffer for electrophoresis tank was prepared and transferred to a clean electrophoresis tank. The gel slab was placed horizontally in the electrophoresis tank and the comb removed gently. The gel was then totally submerged in buffer but not covered by more than $1 \mathrm{~cm}$ above the gel. Five (5) $\mu \mathrm{l}$ of gel loading buffer was added to $15 \mu \mathrm{l}$ of each sample (total $20 \mu \mathrm{l}$ ) and the samples were carefully loaded in individual wells. The set up was then run at 75 volts for 45 minutes. After the dye front has travelled approximately $80 \%$ of the gel length, the gel was removed from the gel tray. Ethidium bromide stained bands in the gel were then photographed using a trans-illuminator (Rederick et al., 1992).

\section{Results}

About 55 bacterial isolates from children with suspected septicaemia were screened for their drug resistant pattern, percentage susceptibility profile of the bacterial isolates by zone of inhibition shows that most of organisms were $100 \%$ sensitive to ceftriaxone except Citrobacter and Proteus, the gram-positive organisms were generally resistant to erythromycin and cefuroxime (Tables 1\&2). Susceptibility of the test bacterial isolates to eight antibiotics using the peak plasma level showed that all the isolates were $100 \%$ susceptible to ceftriaxone with the exception of Citrobacter (50\%) and Proteus spp (0\%) to the test antibiotics (Table 3). The MAR indices showed that the least index was 0.3 while the highest was 0.8 (table 4). All the MAR bacterial isolates were found to produce $\beta$ lactamase enzyme and were observed to be resistant to the $\beta$ lactam antibiotics used in this study (Table 5). Agarose gel electrophoresis of plasmid DNA of the MAR isolates revealed the presence of plasmids. About 2(two) of the MAR isolates has 2 plasmids, while others have only one. The sizes of the plasmid DNA include $10 \mathrm{~kb}, 8.71 \mathrm{~kb}$, $7.08 \mathrm{~kb}, 1.023 \mathrm{~kb}, 1 \mathrm{~kb}, 0.97 \mathrm{~kb}$, and $0.87 \mathrm{~kb}$ (Fig 1\&2). Fig. 3 shows semi-logarithmic graph of the molecular weight of the standard DNA marker vs the distance travelled by the DNA on the gel, this was used to estimate the molecular weight of the isolated plasmid DNA. Table 6 shows agarose gel electrophoresis of plasmid DNA of bacteria isolates with plasmid number and their approximate sizes. 
BAJOPAS Volume 9 Number 2 December, 2016

Table 1: Percentage sensitivity profile of gram positive organisms isolated from children with suspected septicaemia in the Institute of Child Health A. B. U.T. H., Zaria by zone of inhibition.

\begin{tabular}{lll}
\hline Antibiotics & $\begin{array}{l}\text { Staphylococcus } \\
\text { aureus }(\%)\end{array}$ & CoNS (\%) \\
Co-trimoxazole & 50.00 & 50.00 \\
Gentamicin & 45.83 & 75.00 \\
Ciprofloxacin & 0.00 & 50.00 \\
Streptomycin & 29.16 & 50.00 \\
Erythromycin & 0.00 & 0.00 \\
Cefuroxime & 0.00 & 0.00 \\
Ceftriaxone & 100.00 & 100.00 \\
Ampiclox & 4.17 & 0.00 \\
\hline
\end{tabular}

Table 2: Percentage sensitivity profile of gram negative organisms isolated from children with suspected septicaemia in the Institute of Child Health A. B. U.T. H., Zaria by zone of inhibition.

\begin{tabular}{llllll}
\hline Antibiotics & $\begin{array}{l}\text { Salmonella } \\
\text { species (\%) }\end{array}$ & $\begin{array}{l}\text { Pseudomonas } \\
\text { species (\%) }\end{array}$ & $\begin{array}{l}\text { Citrobacter } \\
\text { species (\%) }\end{array}$ & $\begin{array}{c}\text { Klebsiella } \\
\text { species (\%) }\end{array}$ & $\begin{array}{c}\text { Proteus sp } \\
(\%)\end{array}$ \\
\hline Co-trimoxazole & 69.23 & 50.00 & 100.00 & 100.00 & 0.00 \\
Gentamicin & 84.61 & 100.00 & 50.00 & 100.00 & 0.00 \\
Ciprofloxacin & 15.38 & 0.00 & 0.00 & 0.00 & 0.00 \\
Streptomycin & 69.23 & 100.00 & 50.00 & 100.00 & 0.00 \\
Augmentin & 38.46 & 100.00 & 50.00 & 0.00 & 0.00 \\
Ofloxacin & 84.61 & 100.00 & 50.00 & 0.00 & 100.00 \\
Chloramphenicol & 15.38 & 0.00 & 50.00 & 0.00 & 100.00 \\
Ceftriazone & 100.00 & 100.00 & 50.00 & 100.00 & 0.00 \\
Cefuroxime & 0.00 & 0.00 & 0.00 & 0.00 & 0.00 \\
\hline
\end{tabular}

Table 3: Percentage Antibiotic sensitivity profile (using peak plasma level) of bacteria isolated from blood samples of children with suspected septicemia, Institute of Child Health, A.B.U.T.H Zaria.

\begin{tabular}{lllllllll}
\hline $\begin{array}{l}\text { Name of org.(No. of } \\
\text { isolates) }\end{array}$ & GN (\%) & ST (\%) & OFX (\%) & $\begin{array}{l}\text { CP X } \\
(\%)\end{array}$ & $\begin{array}{l}\text { CHL } \\
(\%)\end{array}$ & CXM (\%) & RP (\%) & ER \\
\hline Staph aureus (24) & 41.66 & 29.16 & 41.66 & 0.00 & 12.50 & 12.50 & 100.00 & 0.00 \\
Coag-ve Staph(4) & 50.00 & 50.00 & 75.00 & 75.00 & 0.00 & 0.00 & 100.00 & 0.00 \\
Citrobacter spp(6) & 50.00 & 50.00 & 50.00 & 0.00 & 50.00 & 0.00 & 50.00 & - \\
Klebsiella spp(2) & 100.00 & 100.00 & 0.00 & 0.00 & 0.00 & 0.00 & 100.00 & - \\
Salmonella spp(13) & 84.61 & 69.23 & 84.61 & 15.38 & 15.38 & 0.00 & 100.00 & - \\
Proteus spp(2) & 0.00 & 0.00 & 100.00 & 0.00 & 0.00 & 0.00 & 0.00 & - \\
Pseudomonas spp(4) & 100.00 & 100.00 & 100.00 & 0.00 & 0.00 & 0.00 & 100.00 & - \\
\hline
\end{tabular}

Key: GN- Gentamicin; OFX - Ofloxacin; CHL- Chloramphenicol; RP- Ceftriaxone; ST- Streptomicin; CPXCiprofloxacin; ER- Erythromycin; CXM- Cefuroxime.

Table 4: Multiple Antibiotic Resistance (MAR) Indices of Bacteria Isolated from children with suspected septicaemia in Institute Child Health, ABUTH

\begin{tabular}{|c|c|c|c|c|c|c|c|c|}
\hline \multirow{2}{*}{$\begin{array}{l}\text { No. of } \\
\text { antibiotics to } \\
\text { which org. } \\
\text { are resistant }\end{array}$} & \multirow{2}{*}{$\begin{array}{l}\text { MAR } \\
\text { Index }\end{array}$} & \multicolumn{7}{|c|}{ Frequency of MAR index } \\
\hline & & $\begin{array}{l}\text { S. aureus } \\
(n=24)\end{array}$ & $\begin{array}{l}\text { CoNS (n } \\
=4)\end{array}$ & $\begin{array}{l}\text { Salmonella } \\
\text { Spp (n } \\
=13)\end{array}$ & $\begin{array}{l}\text { Pseudomonas } \\
\operatorname{Spp}(\mathrm{n}=4)\end{array}$ & $\begin{array}{l}\text { Citrobacter } \\
\operatorname{Spp}(\mathrm{n}=6)\end{array}$ & $\begin{array}{l}\text { Proteus } \\
\text { Spp } \\
(\mathrm{n}=2)\end{array}$ & $\begin{array}{l}\text { Klebsiella } \\
\text { Spp } \quad(\mathrm{n} \\
=2)\end{array}$ \\
\hline & 0.1 & 0 & 0 & 0 & 0 & 0 & 0 & 0 \\
\hline & 0.2 & 0 & 0 & 0 & 0 & 0 & 0 & 0 \\
\hline 3 & 0.3 & 0 & 0 & $1(7.7)$ & 0 & 0 & 0 & 0 \\
\hline 4 & 0.4 & $2(8.3)$ & $1(25.0)$ & $7(53.9)$ & $4(100.00)$ & 0 & 0 & 0 \\
\hline 5 & 0.5 & $1(4.2)$ & $2(50.0)$ & 0 & 0 & $1(16.7)$ & 0 & 0 \\
\hline 6 & 0.6 & $9(37.5)$ & 0 & $5(38.5)$ & 0 & $4(66.7)$ & 0 & $2(100.0)$ \\
\hline 7 & 0.7 & $4(16.7)$ & $1(25.0)$ & 0 & 0 & $1(16.7)$ & 0 & 0 \\
\hline 8 & 0.8 & $8(33.3)$ & 0 & 0 & 0 & 0 & $2(100.0)$ & 0 \\
\hline 9 & 0.9 & 0 & 0 & 0 & 0 & 0 & 0 & 0 \\
\hline & 1.0 & 0 & 0 & 0 & 0 & 0 & 0 & 0 \\
\hline
\end{tabular}

The MAR indices showed that the least index was 0.3 while the highest was 0.8 . 
BAJOPAS Volume 9 Number 2 December, 2016

Table 5: $\beta$ - Lactamase production by resistant bacteria isolated from blood of children with suspected septicaemia in the Institute of Child Health, A.B.U.T.H. Zaria

\begin{tabular}{lcc}
\hline Bacterial isolates & Number & $\boldsymbol{\beta}$ - lactamase production \\
Staphylococcus aureus & 3 & 3 \\
Coagulase neg.Staph & 3 & 3 \\
Citrobacter $s p$ & 2 & 2 \\
Klebsiella $s p$ & 1 & 1 \\
Salmonella $s p$ & 3 & 3 \\
Proteus $s p$ & 1 & 1 \\
Pseudomonas $s p$ & 2 & 2 \\
\hline
\end{tabular}

$\begin{array}{llllllllllllllll}1 & 2 & 3 & 4 & 5 & 6 & 7 & 8 & 9 & 10 & 11 & 12 & 1314 & 15 & 16\end{array}$

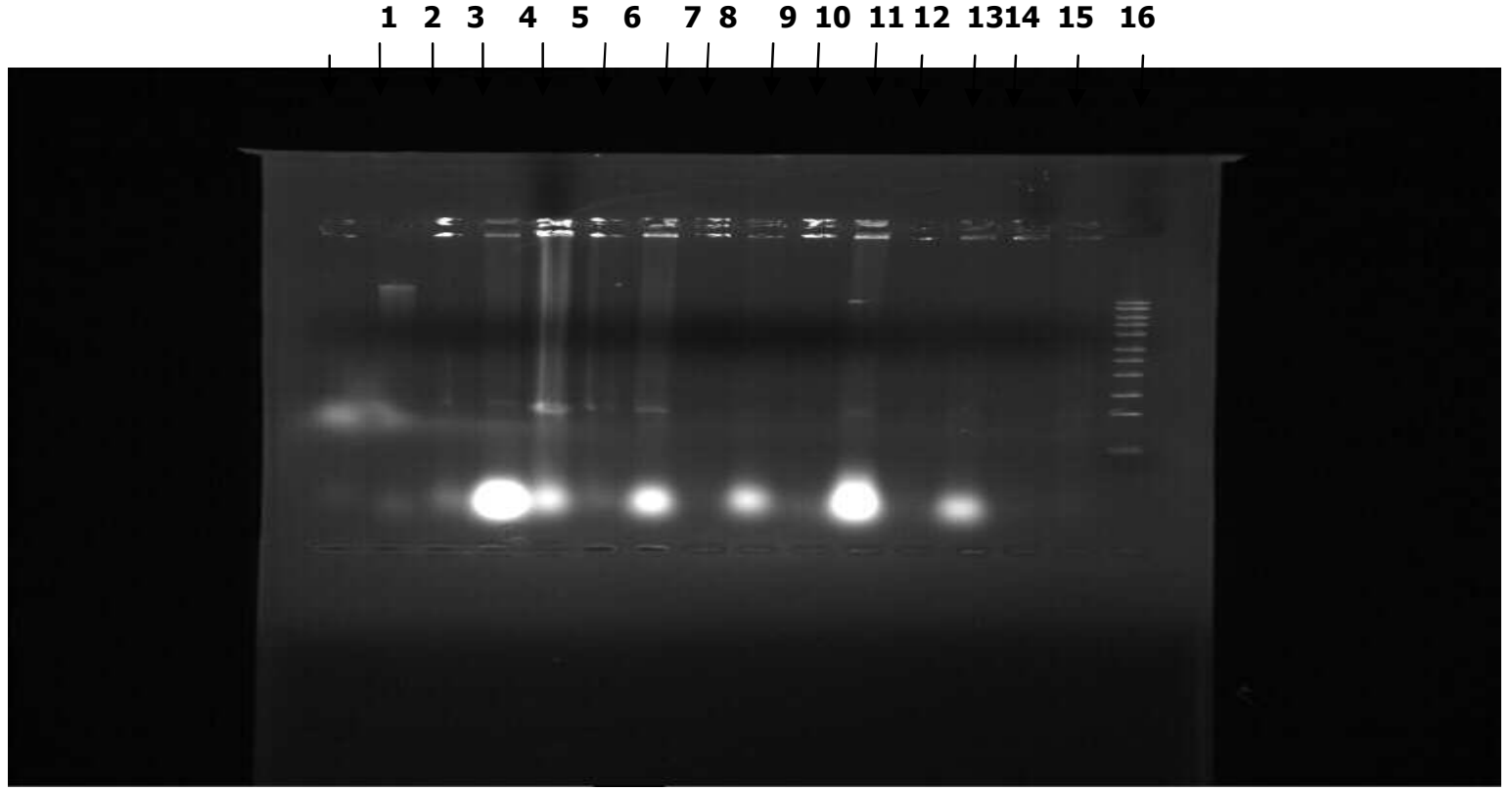

Fig $1 \quad 0.8 \%$ Agarose gel electrophoresis of plasmid DNA from MAR bacteria isolated from children with suspected septicaemia. Lane $1-7$, lane 11, and 16 correspond with isolate laboratory numbers 8, 10, 45, 51, 53, 60, 63, 126, and DNA ladder, showing fragment sizes of $10.00 \mathrm{~Kb} ; 8.00$ $\mathrm{Kb}$; $6.00 \mathrm{~Kb}$; $5.00 \mathrm{~Kb}$; 4.00 Kb; 3.00 Kb; $2.50 \mathrm{~Kb}$; $2.00 \mathrm{~Kb}$; $1.50 \mathrm{~Kb}$; $1.00 \mathrm{~Kb}$ and $0.50 \mathrm{~Kb}$

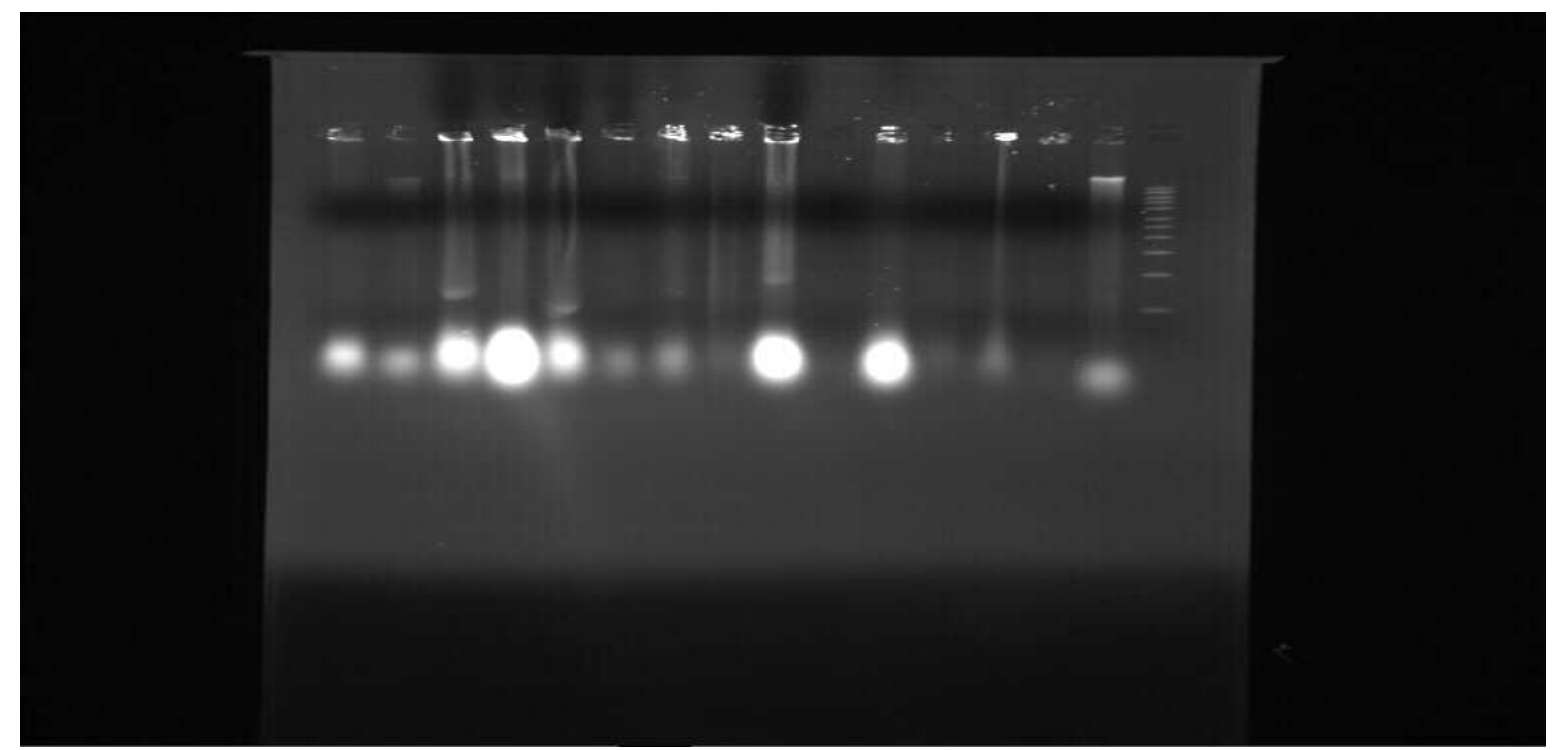

Fig 2: $0.8 \%$ AGAROSE GEL ELECTROPHORESIS OF PLASMID DNA from MAR bacteria isolated from children with suspected septicaemia. Lanes 9 and 15 has lab no. 102 and 135. 
BAJOPAS Volume 9 Number 2 December, 2016

Table 6: Standard molecular weight sizes of the DNA marker

\begin{tabular}{ccc}
$\begin{array}{l}\text { Molecular sizes of standard } \\
\text { DNA ladder }(\mathbf{K b})\end{array}$ & $\begin{array}{l}\text { Log of molecular size of the } \\
\text { marker }\end{array}$ & $\begin{array}{l}\text { Distance moved by the band } \\
\mathbf{( c m})\end{array}$ \\
\hline 10.00 & 4.00 & 1.70 \\
8.00 & 3.90 & 1.90 \\
6.00 & 3.78 & 2.00 \\
5.00 & 3.70 & 2.10 \\
4.00 & 3.60 & 2.20 \\
3.00 & 3.48 & 2.30 \\
2.50 & 3.40 & 2.60 \\
2.00 & 3.30 & 2.80 \\
1.50 & 3.18 & 3.10 \\
1.00 & 3.00 & 3.50 \\
0.50 & 2.70 & 4.10 \\
\hline
\end{tabular}

Table 7: Agarose gel electrophoresis of plasmid DNA of bacteria isolated from suspected septicaemia patients showing plasmid number and their approximate sizes.

\begin{tabular}{cclcc}
\hline S/No & Isolate No. & Bacterial species & Plasmid No. & $\begin{array}{c}\text { Approximate plasmid } \\
\text { size (Kb) }\end{array}$ \\
$\mathbf{1}$ & 8 & Citrobacter spp & 1 & 0.97 \\
$\mathbf{2}$ & 10 & Klebsiella spp & 2 & 8.71 and 0.87 \\
$\mathbf{3}$ & 45 & Citrobacter spp & 1 & 1.023 \\
$\mathbf{4}$ & 51 & Salmonella spp & 1 & 1.023 \\
$\mathbf{5}$ & 53 & Proteus spp & 1 & 1 \\
$\mathbf{6}$ & 60 & Salmonella spp & 1 & 1 \\
$\mathbf{7}$ & 63 & Staph. aureus & 1 & 0.97 \\
$\mathbf{8}$ & 126 & CoNS & 2 & 7.08 and0.87 \\
$\mathbf{9}$ & 102 & Staph.aureus & 1 & 0.97 \\
$\mathbf{1 0}$ & 135 & Pseudomonas spp & 1 & 10 \\
\hline
\end{tabular}

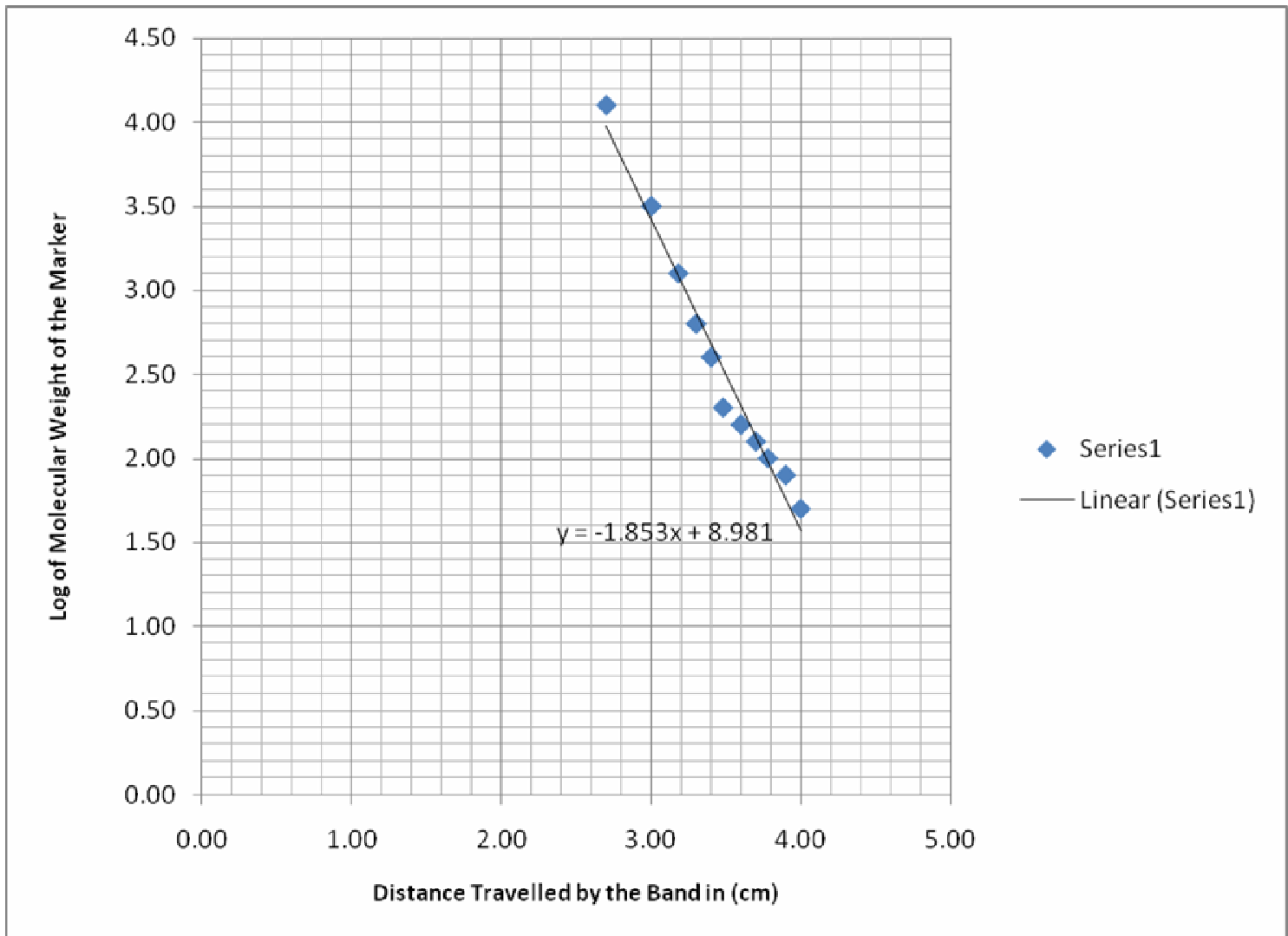

Fig 3: Semi-logarithmic graph of the molecular weight of the standard DNA marker vs the distance travelled by the DNA on the gel. 


\section{DISCUSSION}

The extent to which bacteria develop resistance to antimicrobial drugs and the speed with which they do so vary with different types of drugs. New resistance mechanisms are emerging and spreading globally, threatening the ability to treat common infectious diseases resulting in prolonged illness and death (WHO, 2016) and a number of factors have been reported to be responsible for the spread of antimicrobial resistance genes among bacterial population plasmid mediated being one of the most significant (Huang et al, 2012). The test bacterial isolates in this study displayed high level of multiple antibiotic resistance to some of the test antibiotics. The MAR index determined in this study showed that the test isolates had values equal to and higher than 0.3 .This shows that the test isolates may have come from environment where antibiotics are often used. Since the blood samples used in this study were from out-patients in the community, it could be concluded that there is widespread indiscriminate use of commonly prescribed antibiotics in the locality investigated.

The high level of resistance to the $\beta$-lactam antibiotics correlates with the ability of these isolates to produce $\beta$-lactamase enzyme. All the MAR isolates screened were found to produce $\beta$-lactamase . Such resistance due to $\beta$-lactamase producing bacteria (BPLB) have been reported in clinical isolates (Fashae et al., 2004; Shukla et al., 2004; Siu et al., 1999; Hugo and Russell, 2004). The development of resistance to penicillin in Staph aureus by the production of $\beta$-lactamase quickly decreases the usefulness of penicillin for serious infections especially among hospitalized patients in whom resistant strains are frequently found Murray and Moellering, (1978). Studies have shown that plasmid bearing the gene encoding these $\beta$-lactamases frequently carries gene encoding resistance to aminoglycosides, chloramphenicol, doxycycline and co-trimoxazole (David and Roberts, 2005; Jacoby et al., 2002, Qin et al, 2008). Emergence of $\beta$ lactam associated resistance in children is of seious concern as this class of antibiotic is often used as first line therapy for critical illness (Qin et al., 2008).

This is of serious concern as even the broad spectrum antibiotics such as cefuroxime and Augmentin $₫$ which are widely used empirically for the treatment of septicaemia are included as observed in this study. It has been reported that BLPB may not only survive penicillin therapy, but can also protect other penicillin susceptible bacteria from penicillin by releasing the free enzyme into their environment.

Agarose gel electrophoresis analysis in this study revealed the presence of plasmids in a majority of the multiple antibiotic resistant isolates tested. The molecular sizes of the plasmid DNA observed in this study were $10 \mathrm{~kb}, 8.71 \mathrm{~kb}, 7.08 \mathrm{~kb}, 1.023 \mathrm{~kb}, 1 \mathrm{~kb}$, $0.97 \mathrm{~kb}$, and $0.87 \mathrm{~kb}$. Two (2) of the MAR isolates (Klebsiella sp and CoNS) have two plasmids, with size of $8.71 \mathrm{~kb}, 0.87 \mathrm{~kb}$ and $7.08 \mathrm{~kb}, 0.97 \mathrm{~kb}$ respectively. These organisms were simultaneously resistant to 3 to 4 antibiotics. Reports from some studies have shown that Klebsiella exhibit resistance to multiple drugs, even to the structurally unrelated antibiotics and it habours plasmids that are capable of disseminating drug resistance to other bacterial population (Gutmann et al., 1985; Sanders, 1984; Rasool et al., 2003). The plasmids found in CoNS may have been acquired from the environment as a result of selective pressure. It has also been reported that CoNS is capable of disseminating antibiotic resistance in the community and habours chloramphenicol, erythromycin, streptomycin resistance gene (Kessie et al., 1998).

Pseudomonas spp isolated in this study was found to harbor a single plasmid of molecular weight $10 \mathrm{~kb}$. Pseudomonas aeruginosa has been reported to have different plasmids that mediate resistance to third generation cephalosporins and penicillins through the $\beta$ lactamase enzymes (Jafari et al, 2013), it has also been found to habour plasmids such as pbs 12 and pbs31 which account for a significant level of resistance of PS. aeruginosa especially when exposed to UV irradiation (Anisimova, et al., 1982). Studies have shown that accumulation of resistance factors have rendered Staph aureus immune to a variety of commonly used antibiotics, thus increasing its ability to survive in hostile environs. Staph aureus resistance have been shown to be as a result of acquisition of mecA gene (Neu,1992) especially to a variety of antibiotics whose mechanism of action are similar to $\beta$-lactam antibiotics, as observed in this study. The 2 multiple antibiotic resistant Citrobacter sp used in this study showed the presence of plasmids with $0.97 \mathrm{bp}$ and $1.023 \mathrm{~kb}$. A study has shown that Citrobacter freundii strains habour plasmids that carry one of $\beta$ lactam gene of the TEM family which inactivates such drugs as the ampicillin and extended spectrum cephalosporins (Janda, 2006), this bacteria has also been reported to carry qnrA and qnrB gene which were transferrable (Yang et $a /, 2008$ ). These findings suggest an increasing rate of resistance to some commonly used antibiotics in the treatment of septicaemia, further studies should be carried out on plasmid profiling this will help in epidemiological surveillance of disease outbreaks and also detecting antibiotic resistance pattern.

In conclusion, this study shows the presence of multiple antibiotic resistant isolates which were quite high in children with suspected septicaemia, it also showed that majority of the MAR isolates harboured resistance factor i.e. R-plasmids which probably must have been acquired from MAR resistant bacteria in surrounding environment. Therefore there is a need to monitor and restrict the use and sale of antibiotics to only conditions that require it, this will help reduce the spread resistant factors in the environment, if not we may be challenged in near future of having no useful antibiotics for the treatment of severe and life threatening infections such as septicaemia.

\section{ACKNOWLEDGEMENTS}

We are grateful to the Institute of Child Health, Banzazzau Ahmadu Bello University Teaching Hospital, Zaria for assisting with the clinical isolates, Center for Biotechnology Research and Training, Ahmadu Bello University, Zaria, Kaduna State, Nigeria, in assisting with the plasmid analysis. 
Contribution of authors: AbdulAziz ZA carried out the laboratory work, Ehinmidu JO, Conceived the idea, Ehinmidu JO and Adeshina GO supervised the work, Bugaje MA assisted in the collection of isolates, Yusuf SS and Pala YY assisted in the plasmid analysis.

\section{REFERENCES}

Alausa K.O, Montefiore D., Sogbetun O.A, Ashiru O.J., Arile A.B. and Sobayo E. (1977). Septicaemia in the tropics; A Prospective study, of 146 patients with a high case fatality rate. Scand. J. Infect. Disease, 9: 181.

Anisomova, L. A., Boronin, A. M. (1982); Pseudomonas aeruginosa plasmids controlling resistance to ultraviolet irradiation and increased mutability, Genetika, 18 (8): 1236-44. [Pubmed English abstract (Original article in Russia)].

Brunfitt W. and Leigh D.A. (1969): The incidence and Bacteriology of bacteraemia. Proc Roy Soc. Med., 62: 12394244.

David, L. P. and Robert, A. B. (2005); Extended spectrum $\beta$ lactamases. A clinical update. Clinical microbiology reviews, 18 (4): 657-686.

Fashae K, Aibinu, I. Ogunsola F, Odugbemi T and Mee B. J. (2004); Extended spectrum $\beta$-lactamase (ESBL) in Klebsiella pneumoniae isolates from Septicaemic children in Ibadan, Nigeria, Nig. J. Health and Biomed Sci. 3 (2): 79-84.

Gordon, L. A. and Ronald, E. P. (2005): Approach to therapy for bacterial diseases: Treatment and prophylaxis of bacterial infection in Harrison"s principle of internal medicine $16^{\text {th }}$ Ed. McGraw-Hill companies Inc.

Gutmann, L. R., Williamson, R. M. Kitzis, M. D., Collatz, E., Acar, J. FandGoldstein, F. W. (1985): Cross resistance to nalidixic acid, trimethoprim and chloramphenicol associated with alterations in the outer membrane proteins of Klebsiella, Enterobacter and Serratia. J. Infect. Dis., 151: 501 - 507.

Huang X Z., Frye J. G., Chahine M A., Glenn L. M., Ake J. A., SU W., Mikeljon P. N. and Emil P. L. (2012): Characteristics of Plasmids in Multidrug Resistant Enterobacteriaceae Isolated During Prospective Surveillance of a newly Opened Hospital in Iraq. PLoS ONE 7(7): DOI: 10 1371/journal.pone.0040360

Hugo, W. B. and Russell, A. D. (2004): Pharmaceutical Microbiology $7^{\text {th }}$ Ed. Blackwell scientific publications London. Pp 200-220.

Jacoby, G. A. Chow, N. and Waites, K. B.(2002); Prevalence of plasmid mediated quinolone resistance. Antimicrobial agents chemother, 47:559-56.

Jafari, E., Shakibaie, M. R. and Poormassomi, L. (2013): Isolation of a Novel Antibiotic Resistance Plasmid DNA from Hospital Isolates of Pseudomonas aeruginosa. J Clin Exp Pathol 3 140. doi 10.4172/2161-0681.1000140.

Janda, M.J., Sharon, L.A.(2006); The Enterobacteria.411 pages. http://books.googlecom.ng/books

Kessie, G., Ettayebi, M. Haddad, A.M., Shibl, A. M. Al Shamary, F. J., Tawfik, A. F., Al-Ahdar, M. N. (1998); Plasmid profile and antibiotic resistance in Coagulase negative Staphylococci isolated from polluted water. J. App. Microbiol, 84 (3): 417-442.

Krumpermann P.H. (1983); Multiple antibiotic resistance indexing of Escherichia coli to identify high risk sources of faecal contamination of foods. App Environ Microbiol, 46 :165-170.
All authors participated in literature search and the write-up.

Conflicting interest: The authors have no potential conflict of interest.

Lennette, E.H., Balones, P., Hausa Jr. W.J., and Shadonmu H.J (1990): Manual of clinical Microbiology, Washington DC .pp 10-20.

Neu, H.C. (1992). The Crisis in Antibiotic Resistance, Science, 257:1064-1072.

Odama, L. E. (1990): The phytochemical screening and investigation on the antibacterial action of the bark of Ceiba petandra (L) Gaertn. (Unpublished) Ph. D Thesis, A. B. U., Zaria, Nigeria, Pp 169 - 179.

Olayinka, B. O., Olayinka, .A. T., Onaolapo, J. A. Olurinola, P. F. (2005): Pattern of resistance to vancomycin and other antimicrobial agents in Staphylococcal isolates in a university teaching hospital. Afr. J. of clin and exptl. Microbiol, 6 (1): 46-52.

Qin X., Zerr M. D., Weissman S. J Englund J. A Denno D.M. Klein E J., Tarr P I., Kwong J., Stapp J R., Tulloch L G., Galanakis E. (2008): Prevalence and Mechanisms of Broad Spectrum $\beta$-Lactam Resistance In Enterobacteriaceae: A Children's Hospital Experience. Antimicrob Agents Chemother 52(11) 3909-14. doi: 10. 1128/AAC.00622-08

Rasool, A. S. Ahmad, A. Khan, S. and Wahab, A. (2003); Plasmid borne antibiotic resistance factors among indigenous Klebsiella. Pak. J. Bot., 35(2); 243-248.

Rederick, M. Ausubel, R. B. Robert, E. K. David, D. M. Siedman, J. G. John, A. S. and Kevin, S (1992); Short protocols in molecular biology $2^{\text {nd }}$ Ed. A compendium of methods from current protocols in molecular biology, Harvard medical school. Greene publishing associates and John Wiley \& sons. New York. Pp1-17.

Sanders C.C. (1992): $\beta$-lactamase of gram negative bacteria new challenges for new drugs. Clin. Infect. Dis., 14, 1089-1099.

Shukla, I., Tiwari, R., Agrawal, M. (2004):Prevalence of extended spectrum lactamase producing Klebsiella pneumonia in a tertiary care hospital. Indian. J. Med. Microbiol. 22: 87-91.

Siu, L. K., Po-Liang, L., Po-RenHsueh., Lin, F. M., Chang Shan-Chwen., Kwen-Tay., Luh, Monto Ho and ChinYun lee.(1999): Bacteraemia due to extended spectrum $\beta$-lactamase producing Escherichia coli and Klebsiella pneumonia in a paediatric oncology ward: Clinical features and identification of different plasmids carrying both SHV-5 and TEM-1 Genes: $J$. Clin. Microbiol. 37, (12): 4020-4027.

Woods G.H and Washington, J.A. (1995). Antimicrobial susceptibility test, Dilution and Disc Diffusion methods. In Manual for clinical microbiology, Murray PR (ed) $6^{\text {th }}$ ed. American society for Microbiology, Washington D.C pp 1327-134.

WHO (2016): World Health Organization, Antimicrobial Resistance Fact Sheet. September, 2016. www. who.int $>$ mediacentre $>$ factsheets

Yang H, Hongbin C, Qiwen Y, Chen M and Wang H ( 2008): High Prevalence of Plasmid-Mediated Quinolone Resistance Genes qnr and aac (6')-Ib-cr in Clinical Isolates of Enterobacteriaceae from Nine Teaching Hospitals in China. Antimicrobial Agents Chemother. 52 (12): 4268-73. doi:10.1128/AAC.00830-08. 